\title{
肺吸虫症の疫学的研究
}

(虫卵検出方法について)

\section{An Epidemiological Investigation of Paragonimiasis}

(On Methods of Recovering Eggs of Paragonimus)

\author{
名古屋大学医学部予防医学教室（指導 岡田博教授） \\ 岡田淳 \\ Atsushi Okada \\ Department of Preventive Medicine, Nagoya University School of Medicine \\ (Director: Prof. H. Okada)
}

\section{緒 言}

肺吸虫症は本邦においては，岐阜・新潟・徳島・高知 ・山口・静岡・熊本・大分・長崎掞よび大阪などに広く 分布し, 静岡県に执いては狩野川流域の三島市塚本地方 が濃厚浸淫地として注目されている。

事実，沼津地方のょうに浸淫地を近くに有する場合， 日常の診療に際し肺吸虫寄生者をしばしば経験する。著 者 ${ }^{11}$ は当地方に扔ける本症の集団検診の必要性を痛感 し, 公衆衞生院より分与を受けた V.B.S. 抗原を用い, 1955年から狩野川下流抢よび黄瀬川流域の中学生を対象 とする Screening-test を実施し，その浸淫度を明らか にした。

皮内反応は本症に特異的なものであるが虫卵検出とそ 本症の決定的診断法であることはいうまでもない。これ まで虫卵検出に関する資料としては, 富永 ${ }^{2)}$ ・ Faust $^{3)}$ ・ 小宮および横川45) により喀痰・瓷便について比較検討 され, 北本ら ${ }^{61}$ により気管内洗滌夜より虫卵の検出が報 告されているが，いずれも患者を対象としておこなわれ たものである。皮内反応で初めて Screening されたよ ろな自覚症のない者についての虫卵検出成績の比輘の報 告は少ない。実際に著者む集団検診をおこない, 喀痰・糞 便につき蜺検出を実施して夕たが, 䨋便が喀痰に比し よい検出率を示したが决して満足すべき成績ではない。 著者は虫卵検出率の向上についても検討してきたが，未 だ試みられたととのない胃液について, 喀痰・鉷便と比 較して虫卵検出を扔てなつたところいささか新知見を得 たので報告する。

\section{研究方法}

\section{1. 被検者対象}

狩野川下流 9 校掞よび黄瀬川流域 7 校, 計16校の中学 生全員につき調査した。

\section{2. 皮内反応抗原および制定基準}

公衆衞生院笴生虫研究室作製の V.B.S. 抽出肺吸虫抗 原 ${ }^{78)}$ を用いた。判定基準" も同研究室の方法に準じ た。しかし皮内に抗原を注入したのちの丘疹径の測定の 煩雑を避故るめ, 著者は鉛筆用金属性サックの尖端を 利用し, 外径を $4 \mathrm{~mm}$ のところ采で磨滅し, これを用 いて被検者の前腕屈側上部导圧し, $4 \mathrm{~mm}$ 径の円形圧 痕内一杯に丘疹ができるまで抗原を注入した。

\section{3. 虫郋検出方法}

a. 喀痰: 早朝喀出した喀痰全部を隇菌シャーレに採 らせ, $5 \% \mathrm{NaOH}$ 液を喀痰量の倍量加えょく混和し, 10 ～15分間放置し,その間ときざき擋拌する。その後 2,500 回転 3 分間遠心沈測し, 上清を捨て, 沈渣全部を載物硝 子上に 1 滴ずつ滴下し， $18 \times 18 \mathrm{~mm}$ の被蓋硝子にて覆 い, 全視野中の虫卵を検索した。

b. 糞便：AMS II 法" ${ }^{9}$ によつた。

c. 胃夜 : 早朝空腹時に 胃液検 査用カテーテルを 用 い, 鼻㓐より捙入 (鼻胿, 咽頭粘膜には $4 \%$ キシロカイ ン液を塗布), 胃液全部を採集し, 胃夜少量の場合は微温 湯で洗滌し，洗涤夜も採集した。胃液を太口試験管内に 分注し, 同量つ $5 \% \mathrm{NaOH}$ 液を加えてょく混和し, 2,500 回転 3 分間遠心沈溉し, 上清を捨て, 再び沈渣を 沈澱管に移し， $5 \% \mathrm{NaOH}$ 液を $5 \mathrm{cc}$ 加えて，2,500 回 転 3 分間遠心沈溉し, 沈洫を喀痰検查のときと同様に検 
第 1 表 疫学 的調 查成綪

\begin{tabular}{|c|c|c|c|c|c|c|c|c|}
\hline \multirow{3}{*}{$\begin{array}{l}\text { 河 } \\
\text { 別 }\end{array}$} & \multirow{3}{*}{ 中学校名 } & \multicolumn{3}{|c|}{ 皮内反応成樍 } & \multicolumn{4}{|c|}{ 虫 卵 検 查 成 樍 } \\
\hline & & \multirow{2}{*}{ 検査人員 } & \multirow{2}{*}{ 陽 性 } & \multirow{2}{*}{ 疑 陽 性 } & 喀 & 痰 & 霬 & 便 \\
\hline & & & & & 陽 & 疑 陽 性 & 陽 性 & 疑 陽 性 \\
\hline \multirow{6}{*}{ 狩 } & 三島 市中郷 & 383 & $12(3.1)$ & 2 & $2 / 8$ & $0 / 2$ & $3 / 7$ & 0 \\
\hline & 清 水 村 & 493 & $12(2.4)$ & 1 & $3 / 8$ & 0 & $6 / 10$ & 0 \\
\hline & 沼 津市大平 & 138 & $15(10.9)$ & 6 & $4 / 15$ & $0 / 6$ & $5 / 15$ & $0 / 6$ \\
\hline & " $" \prime \prime \prime$ 大岡 & 654 & $15(2.3)$ & 1 & $4 / 13$ & 0 & $6 / 12$ & 0 \\
\hline & " $" \prime \prime \prime$ 第五 & 1161 & $6(0.5)$ & 1 & $1 / 5$ & $0 / 1$ & $1 / 6$ & $0 / 1$ \\
\hline & "I" " 第四 & 796 & $15(1.9)$ & 1 & $1 / 1$ & 0 & $6 / 12$ & $0 / 1$ \\
\hline \multirow[t]{3}{*}{ 野 } & $\prime \prime \prime \prime \prime \prime$ 第三 & 783 & $29(3.7)$ & 2 & $2 / 5$ & 0 & $14 / 26$ & $0 / 1$ \\
\hline & $\prime \prime \prime \prime \prime \prime$ 第二 & 937 & $6(0.6)$ & 2 & $0 / 3$ & $0 / 2$ & $1 / 6$ & $0 / 2$ \\
\hline & $\prime \prime \prime \prime \prime \prime$ 第一 & 980 & $7(0.7)$ & 1 & $0 / 2$ & 0 & $0 / 4$ & 0 \\
\hline \multirow[t]{3}{*}{ 川 } & $\mathbf{M}$ & 3419 & $86(2.5)$ & 13 & & & & \\
\hline & $\mathrm{F}$ & 2906 & $31(1.1)$ & 4 & & & & \\
\hline & 計 & 6325 & $117(1.85)$ & $17(0.26)$ & $17 / 60$ & $0 / 11$ & $42 / 98$ & $0 / 11$ \\
\hline \multirow{4}{*}{ 黄 } & 御殿場市御殿場 & 939 & $1(0.1)$ & 1 & $0 / 1$ & $0 / 1$ & $1 / 1$ & $0 / 1$ \\
\hline & " " " " " 富士岡 & 478 & $4(0.8)$ & 1 & $0 / 2$ & $0 / 1$ & $0 / 4$ & $0 / 1$ \\
\hline & 裾野町深良 & 213 & $1(0.4)$ & 0 & 0 & 0 & $0 / 1$ & 0 \\
\hline & " $" \prime \prime \prime$ 富岡 & 354 & $1(0.3)$ & 1 & $0 / 1$ & 0 & $0 / 1$ & 0 \\
\hline \multirow{3}{*}{ 瀬 } & " $" \prime \prime$ 東 & 429 & $8(1.9)$ & 2 & $0 / 5$ & $0 / 1$ & $2 / 6$ & $0 / 1$ \\
\hline & 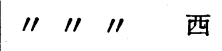 & 360 & $1(0.3)$ & 0 & $0 / 1$ & 0 & $0 / 1$ & 0 \\
\hline & 長 泉 村 & 890 & $13(1.5)$ & 3 & $0 / 9$ & $0 / 1$ & $4 / 13$ & $0 / 3$ \\
\hline \multirow[t]{3}{*}{ 川 } & $\mathbf{M}$ & 1877 & $17(0.9)$ & 4 & & & & \\
\hline & & 1786 & $12(0.7)$ & 4 & & & & \\
\hline & 計 & 3663 & $29(0.79)$ & $8(0.22)$ & $0 / 19$ & $0 / 4$ & $7 / 27$ & $0 / 6$ \\
\hline & $\mathbf{M}$ & 5296 & $103(1.94)$ & $17(0.32)$ & $11 / 59$ & $0 / 12$ & $33 / 89$ & $0 / 11$ \\
\hline & 計 & 4692 & $43(0.92)$ & $8(0.17)$ & $6 / 20$ & $0 / 3$ & $16 / 36$ & $0 / 6$ \\
\hline & & 9988 & $146(1.46)$ & $25(0.25)$ & $17 / 79(21.5)$ & $0 / 15$ & $49 / 125(39.2)$ & $0 / 17$ \\
\hline
\end{tabular}

（）内は\%。分母は検体提出者数，分子は虫卵検出者数。

鏡した。

\section{4. 中間宿主の攝取ならびに接触調査}

感染経路として重要な役割をなすモクズガニ・サワガ ニ・ザリガニの調理後摄取执よび生食ならびに接触頻度 につき，全被検者に調查表を配布し，該当欄を○印で囲 ませ調查した。

\section{5. 被哽幼虫検出方法}

モクズガニの鰓につき，検鏡により被囊幼虫寄生の有 無を調べ，また宮崎 ${ }^{10111}$ の基準により種類を鑑別した。 さらに一部の被囊幼虫を幼大に経口投与し感染せしめ, その成虫の皮棘 ${ }^{11121}$ の生え方を検鏡し，同定の参考とし た。

\section{研究成績}

\section{1. 皮内反応成䋧}

検査人員 9,988 名（男 5,296 名，女 4,692 名）中, 皮 内反応陽性者は 146 名, $1.46 \%$ (男 103名，1.94\%，女 43名， $0.92 \%$ ) であり，疑陽性者は 25 名， $0.25 \%$ (男 17 名, $0.32 \%$, 女 8 名, $0.17 \%$ )である (第 1 表)。

河川別にみると, 狩野川下流 9 校では, 検查人員 6,325 名(男3,419 名, 女2,906 名)中, 皮内反応陽性者は 117 名, $1.85 \%$ (男 86 名, $2.5 \%$, 女 31 名, $1.1 \%$ ), 疑陽性者 は17名， $0.26 \%$ (男 13 名，女 4 名) である。黄瀬川流域 7 校では, 検查人員 3,663 名 (男 1,877 名, 女 1,786 名）中，皮内反応陽性者 29 名， $0.79 \%$ (男 17 名， $0.9 \%$, 女 12 名， $0.7 \%$ ), 疑陽性者 8 名， $0.22 \%$ (男 4 名,女 4 名) 
である(第1表)。

学区別に陽性率㺼及ると(第1 図), 沼津市大平中学校 は10.9\%でもつとも高率である。ついで沼津市第三中学 校の $3.7 \%$, 三島市中郷中学校の $3.1 \%$ ある。御殿 場市御殿場中学校は $0.1 \%$ でもつとも低率である。

\section{第 1 図 狩野川下流・黄瀨川流域の肺吸虫症瀑淫度}

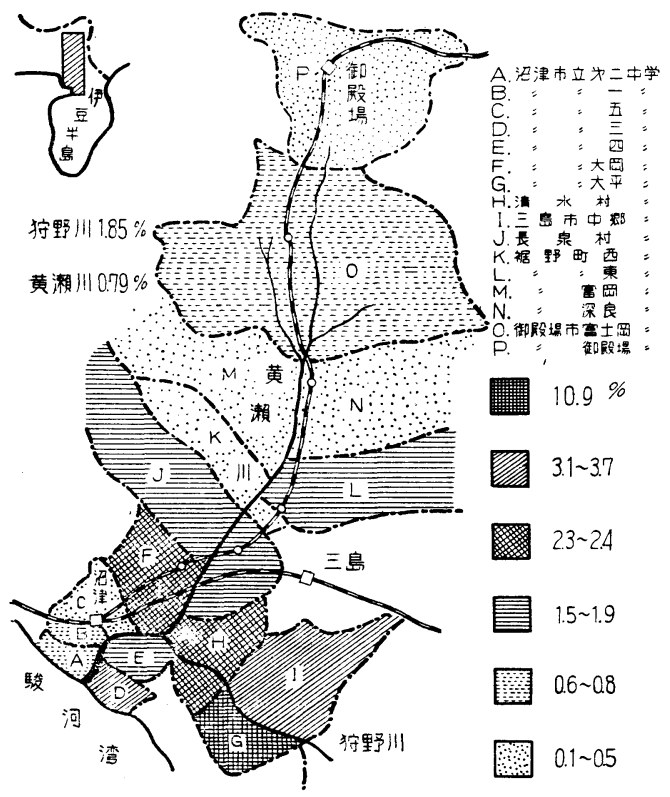

\section{2. 虫卵検出成精（第 1 表）}

a. 喀痰・糞便上りの虫卵検出率：皮内反忘陽性者よ り, 喀痰の提出79名中, 虫卵陽性者 17 名, $21.5 \%$, 糞便 の提出 125 名中, 虫卵陽性者 49 名, $39.2 \%$ ある。疑陽 性者から, 喀痰15名, 糞便17名の検体提出があつたが虫 卵注認められなかつた。 b。胃液よりの虫卵検出率已喀痰・糞便からの虫卵検 出率との比較成績：皮内反応陽性者 60 名につき, 胃液・ 喀痰・糞便の 3 者について同時検查を各々 1 回ずつ扟と なつた。中学生群 42 名において性, 胃液 $66.7 \%$, 喀痰 19.0 $\%$, 冀便 $42.9 \%$ 検出率である。17歳以上群 18 名 (内 1 名は 4 年前入院治療, 1 名は区域切除) に怙いては, 胃 液 $55.6 \%$, 喀痰 $44.4 \%$, 糞便 $33.3 \%$ 検出率である。両 群を総計すると，胃液 $63.3 \%$, 喀痰 $26.6 \%$, 糞便 $40.0 \%$ である。胃液は他の 2 者より $5 \%$ の危険率に㧊いて検出 率が高いというととができる(策 2 表)。

\section{第 2 表 胃液・喀痰および啚便からの 虫卵検出成綪の比較}

\begin{tabular}{c|c|c|c|c}
\hline & 検查人員 & 喀 痰 & 胃 液 & 糞 便 \\
\cline { 1 - 5 } 中学 生 & 42 & $\begin{array}{c}8 \\
19.0 \%\end{array}$ & $\begin{array}{c}28 \\
66.7 \%\end{array}$ & $\begin{array}{c}18 \\
42.9 \%\end{array}$ \\
\hline 17歳以上 & 18 & $\begin{array}{c}8 \\
44.4 \%\end{array}$ & $\begin{array}{c}10 \\
55.6 \%\end{array}$ & $\begin{array}{c}6 \\
33.3 \%\end{array}$ \\
\hline 計 & 60 & $\begin{array}{c}16 \\
26.6 \%\end{array}$ & $\begin{array}{c}38 \\
63.3 \%\end{array}$ & $\begin{array}{c}24 \\
40.0 \%\end{array}$ \\
\hline
\end{tabular}

次に, 集卵数につき 3 者を比較検討した。被蓋硝子全 視野中, 虫卵数 $1 \sim 9$ のものを (十),10以上を (H) と した。（H）は, 胃夜 20 名, $33.3 \%$, 喀痰 8 名, $13.3 \%$, 糞便10名, $16.7 \%$ で胃液がもつとも多く集卵される。喀 痰の 8 名中 7 名は血痰提出者である。（十）快，胃液 18 名, $30.0 \%$, 喀痰 8 名, $13.3 \%$, 糞便 14 名, $23.3 \%$ あ る。すなわち排出虫卵数の少ない場合, 胃液でもつとも よく検出される。

喀痰検查で虫卵陰性者 44 名中, 胃液検査で (H) が 9 名, $15.0 \%,(+)$ が13名, $21.7 \%$ k虫卵を検出し, 糞

第 3 表 虫卵数别にみた胃液・愘痰および萁便内よりの虫卵検出頻度

\begin{tabular}{|c|c|c|c|c|c|c|c|c|c|c|}
\hline & \multicolumn{2}{|c|}{ 䔬 } & 便 & \multirow{2}{*}{ 計 } & \multicolumn{2}{|c|}{ 痰 } & 喀 & & \\
\hline & & - & + & $H$ & & $H$ & + & - & & \\
\hline \multirow[t]{2}{*}{ 胃 } & $H$ & $\left(\begin{array}{c}1 \\
1.7)\end{array}\right.$ & $\begin{array}{c}10 \\
(16.7)\end{array}$ & $\begin{array}{c}9 \\
(15.0)\end{array}$ & $\begin{array}{c}20 \\
(33.3)\end{array}$ & $\left.{ }^{7}{ }^{71.7}\right)$ & $\begin{array}{c}4 \\
(6.7)\end{array}$ & $\begin{array}{c}9 \\
(15.0)\end{array}$ & $H$ & 胃 \\
\hline & + & $\begin{array}{c}14 \\
(23.3)\end{array}$ & $\begin{array}{c}3 \\
(5.0)\end{array}$ & $\left(\begin{array}{c}1 \\
1.7\end{array}\right)$ & $\begin{array}{c}18 \\
(30.0)\end{array}$ & $\left(\begin{array}{c}1 \\
1.7)\end{array}\right.$ & $\begin{array}{c}4 \\
(6.7)\end{array}$ & $\begin{array}{c}13 \\
(21.7)\end{array}$ & + & \\
\hline 液 & - & $\begin{array}{c}21 \\
(35.0)\end{array}$ & $\begin{array}{c}1 \\
(1.7)\end{array}$ & 0 & $\begin{array}{c}22 \\
(36.7)\end{array}$ & 0 & 0 & $\begin{array}{c}22 \\
(36.7)\end{array}$ & - & 液 \\
\hline \multicolumn{2}{|c|}{ 計 } & $\begin{array}{c}36 \\
(60.0)\end{array}$ & $\begin{array}{c}14 \\
(23.3)\end{array}$ & $\begin{array}{c}10 \\
(16.7)\end{array}$ & $\begin{array}{c}60 \\
(100.0)\end{array}$ & $\begin{array}{c}8 \\
(13.3)\end{array}$ & $\begin{array}{c}8 \\
(13.3)\end{array}$ & $\begin{array}{c}44 \\
(73.4)\end{array}$ & \multicolumn{2}{|c|}{ 計 } \\
\hline
\end{tabular}

被蓋硝子全視野 $1 \sim 9(+)$, 10 以上 $(H)$ 。（）内は\%を示す。 
便検査で虫卵陰性者36名中, 胃液検査で（H）が 1 名, 1.7\%（+）が14名, $23.3 \%$ 虫卵学検出しているこ と以注目に值する(第 3 表)。

また参考までに述べるが, 胃液では, 喀痰と同様明るい 視野に多数の虫卵が容易に発見される(写真 $a, b, c) 。$

写真 a. 胃液検鏡所見

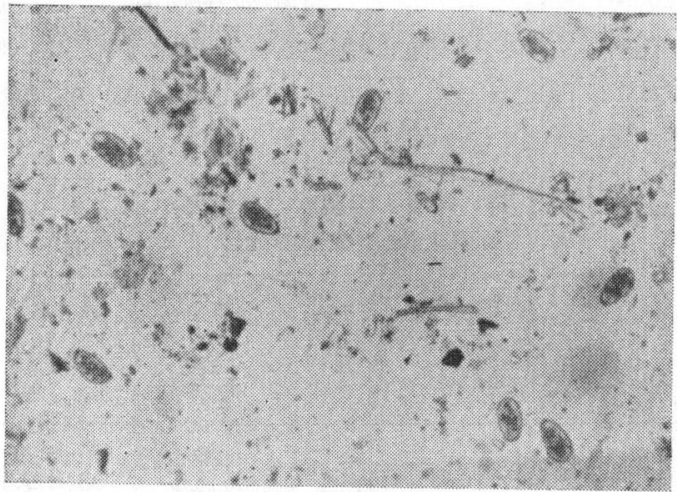

写真 b. 愘痰検鏡所見

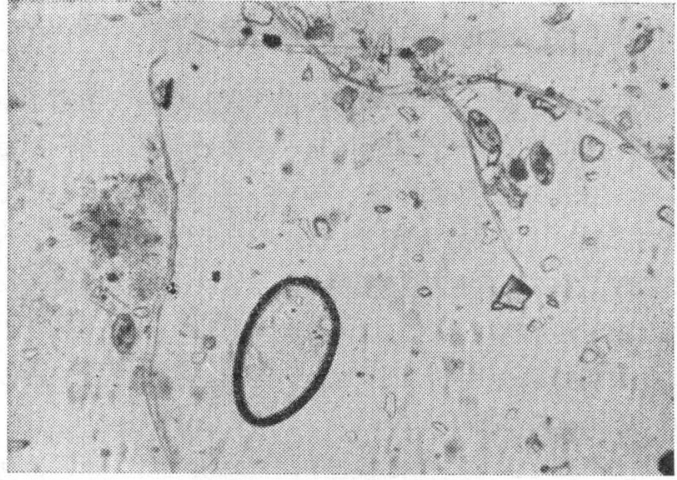

写真 c. 綨便検鏡所見

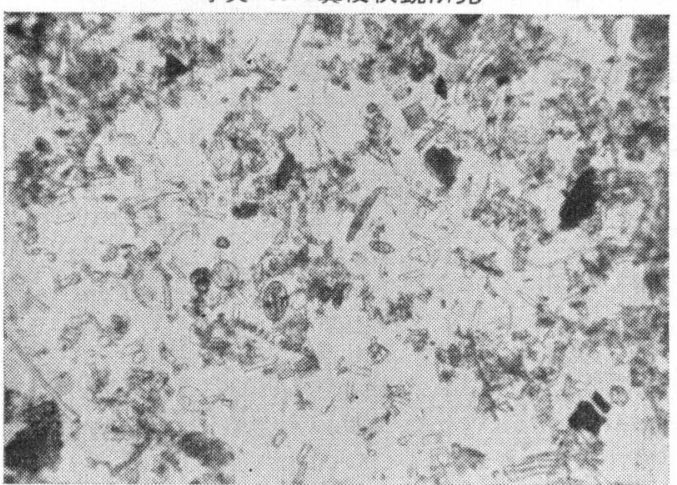

3. 被亮幼虫寄生状況

両河川より採集したモクズガニにつき被囊幼虫寄生率 老調査した(䲘 4 表)。
第 4 表「モクスガニ」の肺吸虫被囊幼虫寄生状況

\begin{tabular}{|c|c|c|c|c|c|}
\hline 河川別 & 捕獲場所 & 検索数 & 奇生率 & $\begin{array}{l}\text { 河川別 } \\
\text { 平均寄 } \\
\text { 生率 }\end{array}$ & $\begin{array}{l}\text { 陽性の力 } \\
=1 \text { 匹当 } \\
\text { Dの仔虫 } \\
\text { 数 }\end{array}$ \\
\hline $\begin{array}{l}\text { 狩 } \\
\text { 野 }\end{array}$ & 中 郷 & & & \multirow{2}{*}{$43.9 \%$} & 13.8 \\
\hline 川 & 狩野川河口 & 42 & $57.1 \%$ & & 11.6 \\
\hline 黄 & 深良 & 25 & $4.0 \%$ & \multirow{2}{*}{$16.0 \%$} & 1.0 \\
\hline 川 & 裾 野 東 & 75 & $20.0 \%$ & & 5.2 \\
\hline
\end{tabular}

狩野川流域の中郷地区より採集した72匹中 $36.1 \%$ 亿, 狩野川河口より採集した42匹中57.1\%に被囊幼虫の寄生 を認め, 狩野川地区の平均寄生率は $43.9 \%$ ある。黄瀬 川流域の深良地区より採集した25匹中 $4.0 \%$, 裾野東 地区より採集した75匹中 $20.0 \%$ 亿被囊幼虫の寄生を認 め, 黄瀬川地区の平均寄生率は16.0\%であり，狩野川流 域の方がはるかに寄生率が高い。

\section{考按}

著者は狩野川下流括よび黄瀬川流域の北部伊豆地方に おける肺吸虫症の流行状況を知る目的で, 中学生を対象 として皮内反応による疫学的調查を执てなつた。抗原と しては横川氏より分与を受けた V.B.S. 抗原を用い, 陽 性率 $1.46 \%$ ，疑陽性率 $0.25 \%$ の成績を得た。

V.B.S. 抗原学用いての疫学調査の報告は横川ら ${ }^{718)}$, 中川ら ${ }^{13)}$ によなされている。以下これらの報告の成績 と対比しながら当地方の浸淫度に考察を加えよう。

横川ら ${ }^{8)}$ は静岡県田方郡函南村の小・中学校および農 業高等学校生徒に実施し, 小・中学校生徒 2,130 名中, 陽 性率 $3.7 \%$ と報告している。著者の調査した隣接の三島 市中郷中学校の成績 $3.1 \%$ に比しやや高率であるが，し かし同様隣接の沼津市大平中学校の10.9\%にははるかに 及ばない。

また, 新潟県直江津地方において小・中学生を対象と して, 横川ら"は5,290 名中, 陽性者 $1.9 \%$, 疑陽性者 $0.3 \%$ ，中川 $\bigsqcup^{131}$ は 14,645 名中, 陽性者 $1.6 \%$,疑陽性 者 $0.48 \%$ あると報告している。な批川ら”の報告に は小・中学校の別が明記してあるので, 中学生だけにつ いてタると, 1,995 名中, 陽性率 $3.2 \%$ ありり, 著者の 成績 $1.46 \%$ に比し 2 倍強である。すなわち当地方に比し 直江津地方は浸淫度が高率である。

また，当地方の調查に括ける性別皮内反応陽性率を みると, 男子は女子の約 2 倍であるが, 横川ら ・中川 ら ${ }^{131}$ も男子は女子の約 2.5 倍であると報告している。 
両河川の浸淫度を比較すると，狩野川1.85\%，黄瀬川 $0.79 \%$ で前者は後者の 2 倍強である。殊に狩野川流域の 沼津市大平中学校は $10.9 \%$ できわて高率である。同じ 流域の沼津の沼津市第一・二・五の 3 中学校は著しく低 率であるが, これは通学区が市街地であり，また地理的 条件から海に親しみ, 川遊びが僅少のため, 蟹に対する 接触頻度の宾少がこのような結果になつたものと考えら れる。黄瀬川流域では上流に行くにしたがい浸淫度は低 下し, 御殿場中学校は $0.1 \%$ で全調查地域を通じてもつ とも低率である。

次に虫卵検出率につき述べれば, 皮内反忘陽性者から 喀痰 $21.5 \%$, 趩便 $39.2 \%$ 虫卵を認め, 疑陽性者からは 検出できなかつた。

翼便検査については皮内反応陽性者尔ら，横川ら》・中 川ら ${ }^{131}$ の検出率は $40.9 \%, 38.0 \%$ 著者の $39.2 \%$ とほぼ 同率であつた。田中 ${ }^{14}$ ) 同様対象者について $2.1 \%$ と低 率であつた。疑陽性者については, 横川ら それぞれ18.7\%，20.7\%と報告しているが，著者は田 中 ${ }^{14)}$ 之同样検出できなかつた。また喀痰検査について,

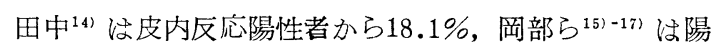
性群少ら $10.3 \% ， 13.6 \% ， 3.2 \%$ と報告し，著者つ 21.5 \%に比し低率であるが, 被検者数と検查法の相違による と考えられる。疑陽性者については, 田中 ${ }^{14)}$ と同様著者 も検出できなかつた。

著者の場合は喀痰および瞥便からの虫卵検出では, 冀 便の方が喀痰に比しょい検出率を示した。小宮掞よび横 川(1) も非定型的喀痰（粘稠で 特有な飴色を帯びていな い）提出者について同様のととを述べている。とのよ

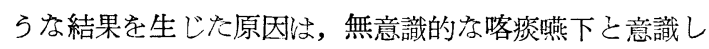
ての喀痰喀出の困難なためと考える。このため著者は嚥 下した喀痰が浮遊する胃液を検体として集卵法を実施し た。乙の試みは肺結核患者の菌検索にもしばしばおこな われ良好な成果を得ているととは周知のと抢りである。

胃夜からの蜺検出を試みたものは未だないが, 著者 は虫卵検出率を, 胃液・喀痰・䶞便の 3 者につき比較し てみたとしろ, 胃夜 $63.3 \%$, 喀痰 $26.6 \%$, 糞便 $40.0 \%$ で あり, 胃夜からの検出率がもつとも優れている。被検者 を中学生群と17歳以上の 2 群について実施して及たが, 胃液が常に喀痰・粪便に比し検出率がよかつた。また肺 吸虫症の治療中の患者 10 名につき, 同一人に 2 ないし 7

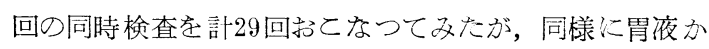
らの検出がもつともよい成績走した。なお中学生群の 喀痰からの虫卵検出率梳わるいが, 乙れ㳊強制的㰸体 の提出を求めたためである。次に胃液採集集卵法につい
て詳細にその利点につき述べるこ，

1）集卵数飞ついて胃液・喀痰・黛便学比較すると 胃液が他の 2 者に比しもつともよく集卵され，な招排 出虫卵数の少ない場合注胃液により初わて螑を検出で きる場合が多い。すなわち喀痰検査で蟖陰性者 44 名 中, 胃夜検查で22名に蜺を検出し, 翼便検查で虫卵陰 性者36名中, 胃液検查で15名に虫卵を検出している。

2）検鏡時の視野についていえば,胃液検查では喀痰 之同様, 視野全体がやや灰白色で明るく, 黄褐色の虫卵 が 32 倍(接眼レンズ $8 \times$, 対物レンズ $4 \times$ ) の弱桩大で容 易に発見でき，かつ内部棈造を知ることができる。これ に反し䨋便検査では着色した沈渣が多く, 視野全体が茶 褐色であり, 虫卵の発見が困難である。志た沈渣中のき わめて微小な固体のため, 被蓋硝子により沈渣が平等に 圧平されず，虫卵が沈渣中に陰蔽され見おとす危除があ

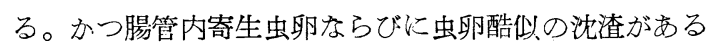
ため, 32倍の弱桩大による検鏡で恬鑑別が困難である。

3）検体採集につき, 喀痰では小児, 中学生, 自覚 症なき患者，ならびに著者の経験した口蓋披裂の患者に 抢いては喀出困難で，たとえ得られたとしても不適当な 検体であるため蜺検出ができない。しかしてれに比し 胃液採集恃すべての者に苦痛なく検出率のよい検体が容 易に得られる。また䨋便検査に比し検出方法ならびに試 薬も簡単である。しかし検体採集に際し, 胃液について は採集用ゾンデを使用するという手数の点でいささか久 点もある。

次に被囊幼虫の奇生状況之両河川の本症蔓延状況との 関係儿つき調查したととろ, 黄瀬川 $16.0 \%$, 狩野川 43.9 \%の寄生率で肺吸虫症の浸淫度と密接な関係があること を知つた。同様なととを福田ら ${ }^{18)}$ ・岩倉 ${ }^{19)}$ ・中川ら ${ }^{13)}$ ・ 大鶴ら 20 も報告している。

被蒙幼虫の感染機会について, 岩崎 ${ }^{21)} \cdot$ 中川 ${ }^{131}$ は調 理時よりも児童の蟹獲り，またはてれをもてあそぶ際が 危険であると述べ，岩崎 ${ }^{211}$ 注漁師らが魚釣り飭に蟹の生 肉使用の危険性について警告している。衣笠 ${ }^{221}$ は台湾に 扮いて蟹の湓漬摂取と捕獲殺害による手指污染を指摘 し, 横川 ${ }^{23)}$ ・岡部ら ${ }^{16)}$ 约調理法を, 亀井 ${ }^{241}$ は生のサワガニ をすりつぶし薬として内服する習慣を重視しているが, 当地方法ける著者の調查では魚鈞り䬣にモクズガニ・ ザリガニの生肉を使用するととがもつとも危険であると 考えられる。な㧍モクズガニに扔ける被囊幼虫寄生率の 季節的变動につき,三浦 ${ }^{25)}$ ・高軋ら ${ }^{26)}$ 亿り $8 ， 9 ， 10$ 月 頃が高率であると報告されて扮り，当地方ではこの季節 が蟹の捕獲時期に当り，乙の時期任感染機会がもつとも 
多いものと考えられ, 新患者の病院外来を訪れる季節が 冬に多いととと符節を合わせ興味がある。

\section{結 論}

北部伊豆地方の狩野川下流怙よび黄瀬川流域の肺吸虫 症浸淫度を知るため, V.B.S. 抗原を用い, 中学生 9,988 名を対象とし皮内反応を実施し, 反応陽性・疑陽性者に ついては喀痰・翼便から虫卵検出を抢てなつた。

また蜺検出率について, 皮内反応陽性者 60 名 (中学 生 42 名, 通院ならびに入院患者 18 名) に胃液・喀痰・䨋 便の 3 者につき比較検討した。

また両河川より採集したモクズガニの被囊幼虫寄生率 と両河川流域の肺吸虫症浸淫度との関係に検討を試及, 次の結論を得た。

1）皮内反応陽性者 $1.46 \%$, 疑陽性者 $0.25 \%$ ある。 地区別に及ると，狩野川下流地区は陽性者 $1.85 \%$, 疑陽

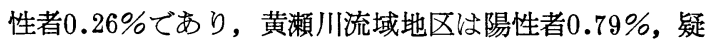
陽性者 $0.22 \%$ であり, 前者の方が浸淫度が高い。虫卵検 出率は陽性者では喀痰 $21.5 \%$, 糞便 $39.2 \%$ ありり, 疑陽 性者からは検出できなかつた。

2）虫卵検出率は胃夜 $63.3 \%$, 喀痰 $26.6 \%$, 粪便 40.0 \%であり，胃液がもつとも優れた検出率を示した。

3）皮内反応陽性率は地区により著しい差異がある。 陽性率の高い狩野川地区の被囊幼虫寄生率は $43.9 \%$ であ り，陽性率の 低い黄瀬川地区の寄生率は $16.0 \%$ であつ た。

擱筆にあたり, 終始御懇切なる御指導と御校閲を賜わ つた岡田博教授に深甚なる感謝の意を表し, また日頃御 助言をいただいた国立沼津病院渡辺駿博士・大庭正博士 に深謝する。

な据, 本論交の要旨は第 28 回日本衞生学会総会に招
いて発表した。

\section{文献}

1）岡田淳 : 第 12 回厚生省国立病院 - 療養所研究総 会口演, 1957.

2) 富永覚仁: 大阪高等医学専門学校雑誌, 9, 153, 1942.

3) Faust, E. C.: Human Helminthology. A manual for physicians, sanitarians and medical zoologists. Philadelphia, 1949.

4）小宮義孝・横川宗雄 : 公衆衞生, 14, 86, 1953.

5) Yoshitaka Komiya et al. : Japanese Journal of Medical Science and Biology, 6, 207, 1953.

6) 北本治 - 他 : 呼吸器診療, 13, 92, 1958.

7）横川宗雄 - 他 : 日本医事新報, 1634, 19, 1955.

8）横川宗雄 : 臨床病理, 4, 224, 1956.

9) Hunter, G. W. III, et al. : Bulletin U. S. Army Medical Dept., 8, 128, 1948.

10）宮崎一郎：医学々生物学, 10, 223, 1947.

11）宮崎一郎: 臨床之研究, $31,423,1954$.

12）宮崎一郎 : 福岡医学雑誌, 37, 195, 1944.

13）中川晃子・平野多聞：寄生虫学雑誌, 5,370 , 1956.

14）田中徳郎 : 長崎医学会雑誌, 32, 1404, 1957.

15）岡部浩洋・他 : 久留米医学会雑誌, $19,486,1956$.

16）岡部浩洋・他 : 久留米医学会雑誌, $20,488,1957$.

17）岡部浩洋・他 : 久留米医学会雑誌, $20,653,1957$.

18）福田武夫・他: 医学々生物学, 34, 81, 1955.

19）岩倉利明 : 医学々生物学, 27, 161, 1953.

20）大鶴正清 - 他 : 寄生虫学雑誌, 7, 147, 1958.

21）岩崎基 : 臨床内科小巟科，10，207，1955.

22）衣笠勝 : 台湾医学雑誌, 38, 277, 1939.

23）横川宗雄 : 公衆衞生, 11, 19, 1952.

24）亀井鼎三 : 実験医報, 26, 1065，1940.

25）三浦守・他 : 熊本医学会雑誌, 29, 77, 1955.

26）高亀良彥・他：日本寄生虫学会第 15 回総会演説 要旨.

(受付 : 1958 年 9 月 17 日) 